\title{
A Double-edged Sword: Swords, Bodies, and Personhood in Early Medieval Archaeology and Literature
}

\author{
Duncan Sayer ${ }^{1}$, Erin Sebo ${ }^{2}$ and Kyle Hughes ${ }^{3}$ \\ ${ }^{1}$ School of Forensic and Applied Sciences, University of Central Lancashire, Preston, UK \\ ${ }^{2}$ College of Humanities, Arts and Social Sciences, Flinders University, Adelaide, \\ Australia \\ ${ }^{3}$ School of English, Trinity College Dublin, Ireland
}

In Anglo-Saxon and Viking literature swords form part of a hero's identity. In addition to being weapons, they represent a material agent for the individual's actions, a physical expression of identity. In this article we bring together the evidence from literature and archaeology concerning Anglo-Saxon and Viking-age swords and argue that these strands of evidence converge on the construction of mortuary identities and particular personhoods. The placement of the sword in funerary contexts is important. Swords were not just objects; they were worn close to the body, intermingling with the physical person. This is reflected in the mortuary context where they were displayed within an emotive aesthetic. Typically, swords were embraced, placed next to the head and shoulders, more like a companion than an object. However, there are exceptions: graves like Birka 581 and Prittlewell show sword locations that contrast with the normal placement, locations which would have jarred with an observer's experience, suggesting unconventional or nuanced identities. By drawing on literary evidence, we aim to use the words of the Anglo-Saxons and Vikings to illuminate the significance of swords in mortuary contexts and their wider cultural associations.

Keywords: swords, mortuary aesthetics, personhood, literature, body, Viking, Anglo-Saxon, Birka, performance of masculinity

\section{INTRODUCTION}

In early medieval literature, warriors are typically associated with a specific weapon, which is part of their heroic identity (Webster, 1998). Often, such weapons are named and their history-the warriors who have carried them and the battles they were used in-is recounted like that of a hero (Culbert, 1960; Khanmohamadi, 2017). Although many types of weapons are mythologized in this way, swords are the most common. Similarly, the archaeological record suggests that swords interweave a series of cultural, personal and physical relations (Ingold, 2010; Paz, 2017; Lund, 2017). Medieval swords are not physically or socially static objects. Their shape was altered with use and they were often adapted by swapping hilts, guards, or wrapping. Swords were typically owned by several people in the course of their use and this contributed to the construction of their identities (Brunning, 2013, 2017). Swords require close quarter combat, so sword fighting is, by its nature, more personal and intimate and, perhaps for that reason, swords seem to carry 
memories, imbuing them with ancestral qualities. They become the agents in stories, defining status, generating events and creating or recreating identities (Kopytoff, 1986; van Houts, 1999; Williams, 2005). In both the literary and the archaeological records, it appears that swords, like warriors, gained status with age and deeds; interestingly, in literature, swords are only buried after a long career or if there is no heir to claim them, an idea that appears reflected in the archaeological evidence. Here, swords deposited among grave-goods tend to be old, or at least were considered old when they were put into the ground (Brunning, 2019). Buried swords are also frequently associated with status in the interpretation of Early Anglo-Saxon and Viking graves (Härke, 2000; Hadley, 2008). Rather than being contradictory, archaeology and literature used together can deepen our understanding of swords and the construction of particular personhoods in the Early Middle Ages.

This article takes an innovative methodological approach, not only by combining archaeological and literary evidence, but also in its approach to this evidence. We use archaeological evidence to discuss the location of swords in burials and, more importantly, to explore personhood as presented in the mortuary context. This expression of personhood manifests itself in the merging of the body with swords within a performative context since the objects were positioned by mourners who had to climb into the grave themselves, which the literary evidence helps to illuminate. Poetry has sometimes been seen a problematic source of evidence since it only describes mortuary contexts incidentally (Price, 2008). However, it is this very quality which makes it an excellent source for examining social expectations. Although literature recounts extraordinary events, it must reflect familiar customs, attitudes, and assumptions in order to engage its audience. Identifying these allows us to explore the context and narrative construction which engenders mortuary performance (Price, 2010).

Our study of the physical association between individuals and swords is based here on Anglo-Saxon and Viking-age contexts in the UK and Scandinavia. This geographical focus complements the locations which the literature discussed here recalls, and it also allows us to explore the interaction between body and weapon in graves from different cultural contexts. We examine the intersection of persons and swords by exploring how they were used to construct identities in poetry and intermingle with archaeological bodies. Swords are often examined as objects; however, we contend that in both literature and archaeology swords were associated with a person, inseparably intermeshed with a particular identity; their presence in a narrative or in the grave was part of the emotive context, contingent on social and personal circumstances.

Weapons are pluralistic objects, both functional and capable of wounding and killing, but also embodying values associated with identity, personhood, gender, and age. A sword is thus a practical, semiotic and symbolic object. It is a status symbol, a badge of class or group membership, and, since it takes practice to use, it changes the person it encounters (Kopytoff, 1986). Swords are transformative and used alongside other material culture in the construction and performance of an individual (Martin, 2014; Felder, 2015; Harrison, 2015). Similarly debates about personhood encapsulate the aesthetic body, material, and semiotic relationships (Fowler, 2010a). Today, shoes which take on the shape of the body and are used in sports, social performance, sexualized behaviour, and as markers of rites of passage or class may be a reasonable 
analogy. A skateboarder might repair a shoe with tape or glue in certain spots, a practical response to damage, but this is also a semiotic act allowing one accomplished skateboarder to recognize another (Steele, 1998). Another analogue might be found in the fact that a charismatic or eccentric personality may 'get away with' odd combinations of clothing, e.g. white trainers and a suit, where as a business or civic leader could not (Hockey et al., 2013; 2015). In the right combination objects can produce an empowering aesthetic which embodies and expresses cultural values seen in art, literature, and storytelling. Specific non-human things can be described using enigmatic, multi-layered or animistic language through which they can be ascribed person-like or empowering qualities (Paz, 2017; Lund, 2017).

\section{Swords in Anglo-SaXon Literature}

Swords have a specific status in AngloSaxon literature. In Irish, Welsh, and Scandinavian literature, names are recorded for spears, axes, and other weapons, such as Gáe Bulga, the spear of the Irish hero, Cúchulainn, or the Norwegian King Magnus' axe Hel. However, in Anglo-Saxon literature only swords bear names. The tendency to anthropomorphize is most clearly demonstrated in the Anglo-Saxon riddles on swords which always imagine them as warriors. Tatwine's eighth-century riddle, De Ense et Vagina, describes the sword as having 'cordis compagine' (1. 1), the 'heart of a warrior', while the sword in Aldhelm's riddle De Pugione vel Spada (also eighth century) says 'domini...nitor defendere vitam' (1. 5) 'I fight to defend the life of my lord'. In the Exeter Book (of which the earliest extant copy dates to the tenth century, though the texts may well be earlier) there are two sword riddles. The sword in riddle 80 describes itself 'Ic eom xpelinges eaxlgestealla' ( $K-D$ 80, 1. 1), 'I am a warrior's shoulder-companion', a term that is usually used of a fellow warrior, while the sword in riddle 20 says it follows a 'waldend', a lord (though the word literally means 'wielder') and that:

'oft ic gæstberend

cwelle compwæpnu cyning mec gyrweð since 7 seolfre $7 \mathrm{mec}$ on sele weorpað'

$(K-D$ 20, 1. 8b-10)

('often I kill men with war weapons.

The king adorns me with jewels and silver and praises me in the hall').

Here, again, the sword is being described in exactly the same terms that a warrior would typically be described in heroic poetry. Interestingly, the reference to being adorned is repeated throughout the riddle, suggesting that it is part of the idea of a sword that it is altered and decorated, especially after victories, so that each alteration would contribute to the sword's history.

Swords are not only anthropomorphized, they are depicted almost as though they have a character and agency. For example, in the dragon fight in the seventh- or eighth-century poem Beowulf (Neidorf, 2016), the hero's sword is described almost as though it were a person, with moral responsibilities: it 'geswac/ nacod æt niðe swa hyt no sceoldes' (Beo. 1. 2584b-5) ('failed as it should not have done, naked in violence'). Often, swords are introduced in more detail than heroes. When Wiglaf joins Beowulf at the crucial moment in the fight against the dragon, he is introduced in two and a half lines:

'Wiglaf wæs haten Weoxstanes sunu leoflic lindwiga leod Scylfinga maeg Ælfheres' (Beo. 1. 2602-2604a) ('He was called Wiglaf, Weohstan's son, dear shield-fighter, man of the Scyldings, Ælfhere's kin'). 
By contrast, his sword's history is given more than five times as many lines and the poet includes both the story of how the sword came into the possession of Wiglaf's family and to Wiglaf himself. This emphasis on the heritage of swords is pervasive: 'ealde lafe' (Beo. 1. 795b; 1488b; 1688a) ('old heirlooms), 'gomelra lafe' (1. 2563), ('ancient heirlooms') and even by the compounds 'ealdsweord' (Beo. 1. 1558a; 1663a; 2616a; 2979a and Mal. 1. 46), ('old-sword'), 'gomelswyrd' (Beo. 1. 2610 b), ('ancient-sword') and 'yrfelafe' (Beo. 1. 1903 a) ('old heirloom'). The literature reveals a belief that swords are hardened and improved by use in battle: 'waepen wundum heard' (Beo. 1. 2687b) ('weapons hardened by wounds'), so that an old sword, passed down from previous battles and tested in combat, is regarded as better and more trustworthy than a new sword. This attitude is even found in the tenthcentury poem Battle of Maldon: the Anglo-Saxon leader, Brythnoth taunts the messenger of the attacking Vikings:

'Hi willað eow to gafole garas syllan ættrynne ord and ealde swurd' (Mal 1. 46-7)

('They will pay you a tribute of good spears, deadly barbs and old swords').

Unlike the other weapons listed here (spears and arrows), the defining and best quality in a sword is that it is old, which presumably implies that it has been gifted, or passed down. Moreover, one of the words for 'sword' in poetry is laf which means 'heirloom'; this word is not used as a term for any other kind of object, and it therefore seems to convey a sword's specific emotional and symbolic significance. There is even a notion that warriors can be 'waepnum gewurpad' (Beo. 1. 331a) 'made worthy by weapons'; when Beowulf and his men arrive at the Danish court, the herald recommends that the king see them because 'hy on wiggetawum wyrðe pinceað/ eorla geæhtlan' (Beo. 1. 368-9a) 'from their war-gear, they seem worthy of the esteem of warriors'. Beowulf himself gives the Danish watchman a sword "pæt $\mathrm{h}$ syðpan wæs/ on meodubence mapma py weorpre/ yrfelafe' (Beo. 1. 1901-1903a) ('so that afterwards on the meadbenches, he had more honoured because of the old heirloom'.

In some contexts, inheriting a sword may even be the mark of a warrior, as the case of Wiglaf demonstrates. His father, Weohstan,

\section{'fræetwe geheold fela missera}

bill ond byrnan oð ðæt his byre mihte eorlscipe efnan swa his aerfædergeaf him ða mid Geatum guðgewaeda aeghwæs unrim pa he of ealdre gewat' (1. 2620-2624)

('...held the treasures for many yearsthe sword and armour-until his son became a warrior like his old father. Then, among the Geats, he gave him the war-gear, much and of many kinds. Then he left this life').

This attitude is not only found in literary but also in documentary texts. Athelstan's will (980s-1014 CE) records a bequest to his brother, the future King Edmund (before 990s-1016 CE), of a sword (apparently) centuries old; "pæes swurdes pe Offa cyng ahte', 'the sword that King Offa had' (Tollerton, 2011), in what seems to have been an endorsement of his future leadership (Danet \& Bogoch, 1994).

Perhaps the most interesting demonstration of the symbolic power of swords is when Beowulf predicts the failure of Hroðgar's truce. He imagines one Heathobard saying to another:

'Meaht ðu, min wine, mece gecnawan pone pin fæder to gefeohte bær under heregriman hindeman siðe, dyre iren, pær hyne Dene slogon, weoldon wælstowe, syððan Wiðergyld læg, 
æfter hælepa hryre, hwate Scyldungas?'

(Beo. 1. 2047-2052)

('Can you, my friend, recognize the blade which your father bore into battle, beneath his helmet on his last campaign, the precious iron swordwhere the Danes killed him, conquered on the battlefield, once Withergyld fell, after the warriors' defeat, the valiant Scyldings?')

The assumption is that a warrior who sees another carrying his father's sword will seek revenge. This sword has greater symbolism than the father's killing alone and motivates a hereditary agency in which a son seeks to restore his father's legacy. The death does not prevent the warrior from making and accepting the truce but the sight of a former enemy carrying the sword ensures the warrior will break the treaty (Sebo, 2011).

\section{Swords in Scandinavian Literature}

Although other kinds of war-gear are named in Scandinavian heroic literature, here too swords are the dominant heroic weapon. As in the Anglo-Saxon literature, a battle-tested sword is a more certain proposition in the heat of battle, where untested weapons are something of a gamble. Consequently, the (typically young) living hero reclaiming an old sword (usually from the less-than-enthusiastic resident of a burial mound) is a common trope in the sagas. Not all weapons need to be won this way, however, and swords gain additional significance when handed down, from one accomplished or notable warrior to another. This action has the effect of bestowing the sword's pedigree and virtue to its new owner, confirming an heir's status or connecting an outsider to an illustrious tradition.

Perhaps the most obvious example of such a sword is the cursed Tyrfingr, whose creation is detailed in the Poetic Edda, and whose tragic career is charted in Hervarar saga ok Heidreks and the supporting material. Interestingly, Tyrfingr is more important as a symbol than as a weapon at the beginning of Hervarar saga. It is taken as a spoil of war and then passed down. The shield maiden Hervor, in her quest to avenge her father Angantyr, traces reports of his death to the island of Samsey, where she takes the unusual step of calling him out of his burial mound to demand the sword: 'Trauðr ertu / arf at veita / eingabarni.' (Hervarar saga, ch. 4) 'You are slow to give that inheritance to your only child'. It is clear from Hervor's choice of words, and specifically from her use of arfr, 'inheritance,' that she views Tyrfingr as her birthright, even though it has not explicitly been declared so. Despite his reluctance, Angantyr acknowledges the validity of her claim. The sword belongs to Hervor, as the representative of that family and as her father's heir and avenger, and it will do so for the rest of her career as a warrior until it is passed on down through her family. Perhaps more interestingly, Tyrfingr is cursed to kill every time it is drawn and to commit three evil deeds. In practice, this means Tyrfingr kills many of its owners, a feature which imbues it with a kind of personhood.

Weapons also have a particular significance as gifts, depending of the status and relationship of those engaged in the exchange. Here the weapon, whether or not it has a name already, may be referred to in the same manner as other important gifts: by a compound name made up of the giver's forename and the ending -nautr, 'gift.' Thus, for example, the sword Skefilsnautr, in Reykdcela saga, is recognized as the sword given by Skefill (in this case, to the warrior Porkell Geirason). A -nautr weapon is more than a gift, it is an extension of the giver and embodies a sort of emotional or symbolic connection 
between giver and recipient, gaining a character of its own (Miller, 2007). In Reykdcela saga, for example, Porkell returns a sword taken from the warrior Skefill's grave that he had used to kill a rival; he is visited the following night by the spirit of the dead Skefill. Skefill praises him for his achievement, and ultimately offers the weapon on the grounds that 'ek parf pat nú ekki, enn pú ert svá vaskr maðr at ek ann pér allvel at njóta.' (Reyk, 67) 'I don't need it now, and you are so valiant a man that I am wholly pleased that you should have it.' When Porkell wakes the next morning, the weapon is by his side, a token of esteem and a symbol of achievement from one dead hero to a living one.

\section{Other Kinds of Weapons in Anglo- Saxon and Scandinavian Literature}

In a few instances, warriors are defined by weapons other than swords. However, this generally indicates something about the nature of the hero, that he is unconventional in some way. The most obvious Anglo-Saxon example is Beowulf, who, unlike his men, is not 'waepnum gewurpad' (Beo. 331a) 'made worthy by his weapons', and who is regarded as a hondbana, a warrior who kills with his bare hands (Sebo, 2011). Although he is associated with a least six different swords, some of which he gives as gifts, the three he uses during the course of the poem fail, and the poet says:

'Him pæt gifeðe ne wæs pæt him irenna ecge mihton

helpan æt hilde; wæs sio hond to strong,

se ðe meca gehwane, mine gefræge, swenge ofersohte' (2682b-6a).

('It was not his fate that the edge of iron weapons could help in battle-his hand was too strong - that every blade, as I have heard, he overtaxed).
Instead, his characteristic war-gear is the armour made by Weland that belonged to Hrethel and saves his life against Grendel's Mother; he asks for it to be returned to his lord if he dies fighting Grendel, and wishes he could leave to a son as he is dying.

Although swords are also the norm in medieval Scandinavian literature, here there is a much greater variety of significant weapons. Perhaps the most notable example is Njála's Gunnarr Hámundarson's atgeirr (a spear or pole weapon). Like Beowulf, Gunnarr's unconventional choice of signature weapon indicates his freakish capacities. He is not only strong and large, but explicitly 'manna bezt vígr,' (Njála, 53) 'the best of men in combat,' unmatched in games or feats of arms, capable of such fighting with either hand, and able to achieve such outlandish feats as being able to leap, fully encumbered, more than his own height, swim like a seal, and swing a sword so quickly that 'at prjú póttu á lopti at sjá (Njála, 53) it appeared that there were three [swords] in the air [at once]'.

Similarly, while it may not possess the long and illustrious pedigree of more famous named weapons, the origins of Gunnarr's atgeirr suggest that it stands apart from other weapons. Originally the possession of the warrior Hallgrimr, the unnamed atgeirr is said to have been "látit seiða til' (Njála, 80), 'wound about with sorcery' to prevent Hallgrímr from being killed by anything but the weapon itself. It is likewise thought to be able to foretell death, singing aloud or ringing out when someone is about to be killed by it. Indeed, while it may not have an identifying name, Gunnarr's atgeirr can be said (with a mostly unintentional pun) to 'speak for itself.' In 51 references to the weapon, each time (save for its introduction and one attribution as 'Gunnarr's atgeirr'), the definite form is used-atgeirinn-in place of the more customary use 
of the indefinite for an unnamed weapon (Orkisz, 2016, p.187). It is simply 'the atgeirr,' as there is no question who it belongs to, or who it is characteristic of.

Although he retains his other weapons, the atgeirr, from the time of Gunnarr's claim onwards, is inseparable from the man himself. It marks him apart from his many luckless rivals, and, perhaps more importantly, it remains onstage after his death, to act as an indicator of his son Hogni's eventual succession to the heroic mode when he avenges his father. Gunnarr's mother, Rannveig, takes the interesting step of refusing to bury the weapon with her son, declaring that it must be passed down, though only to the one who takes vengeance. There is, of course, no more suitable candidate than Hogni, who, of Gunnarr's two sons, is the most like him, if slightly less motivated to feats of valour. The atgeirr becomes his nudge into that world, a final gift from Gunnarr, who had previously made his presence manifest in the burial mound apparently to spur on his son. When Hogni goes to retrieve the weapon, it responds in clear fashion:

'Hogni tekr ofan atgeirinn, ok song í honum. Rannveig spratt upp at œði mikilli ok spurði: "Hverr tekr atgeirinn, par er ek bannaða ollum með at fara?" "Ek ætla," segir Họni, “at fœra fờur mínum, ok hafi hann til Valhallar ok beri par fram á vápnapingi." "Fyrri muntú nú bera hann ok hefna fờur píns," segir hon, "pví at atgeirrinn segir manns bana, eins eða fleiri” (Njála, 194).

('Hogni took down the atgeirr, and it sang out. Rannveig sprang up in a great anger and asked: "Who is taking the atgeirr, when I forbade anyone from taking it away?" "I intend," said Hogni, "to bring it to my father, so that he can have it in Valhalla and take it to battle." "First you will bear it now, and avenge your father," she said, "because that atgeirr announces death, for one man or more"').

While not explicitly bequeathed from father to son, the ringing of the atgeirr in this moment recalls both the weapon's supernatural origins and aspects, and their manifestations twice at pivotal moments in the life of Gunnarr. It is no coincidence that, following Gunnarr's death, his mother subverts expected tradition and expressly forbids the burial of the weapon with its owner; this was the moment that she was waiting for. Hogni's removal of it, and use in fulfilment of Rannveig's wishes, signifies a change in ownership similar to that effected by Gunnarr's own taking possession of it, and when the son exits the saga following this final act of vengeance, he takes with him his father's weapon and legacy.

\section{The Materiality of Early Medieval SWORDS}

The literature suggests that swords both become identified with their owner and that the swords are identifiable. Consequently, the decoration and wear visible on a sword is significant. As Brunning (2013; 2017) argues, wear makes a sword unique, visually identifiable, and gives it a life-history, or even 'person-like' qualities. For example, the sixth-century silver-gilt ring-pommel from grave 39 at the cemetery at Bifrons in Kent has lost its surface gilding, while the sword from grave $\mathrm{C}$ at Dover Buckland (also in Kent) shows signs of heavy wear and marking at the apex of the pommel from being worn (Brunning, 2017: 441). Other examples include swords from the Kentish sites of Broadstairs, Sarre, Faversham, and Saltwood, as well as Scandinavian swords, including those from 
boat grave XII at Vendel, and both swords from grave 6 at Valsgärde in Sweden (Brunning, 2013: 123-25). These differences reflect each specific, symbiotic relationship. Swords wear with contact which differs depending on the physical dimensions and biomechanics of the carrier, and on how and if the sword is worn. Grips, naturally, also wear differently depending on their construction, composition, wrapping, use, and user. For example, the sword from boat grave I at Vendel shows evidence of wear from use on its metal handle (Brunning, 2013: 128). The user's body also adapts, developing calluses, muscle, or new habits of movement to accommodate the sword. In these ways, a sword becomes part of the person, aesthetically associated with them, and physically adapted in a form of relational personhood (Fowler, 2010b). Given this symbiotic relationship, it is not surprising that early medieval literature reflects a sense that inherited swords carry with them part of their previous owner. In other words, a weapon can convey intergenerational agency. Gunnarr Hamundarson's weapon, the atgeirr, has this broader significance: it is taken up by his son in order to seek vengeance, not just a spear but also as a tool to continue an intergenerational feud. In fact, this narrative implies that the feud could have ended if no one had taken up the atgeirr. The next generation seems to have had some choice, a feature reflected in several Germanic legal codes (Jurasinski, 2006; Sebo, 2015). Similarly, Hrómundr's sword is not just simply a trophy, it helps him secure marriage and join a royal family.

The literature also stresses the value placed on old swords, an element which is reflected in a range of ways in the archaeological record. Tania Dickinson, for example, noted that the fittings on the sword in grave 31 at Brighthampton (Oxfordshire) were not stylistically consistent: 'the deep chip-carved scabbard mouth is quite different from the chape with its plane, plated ornament, and both are distinct from the neat equal-armed silver cross which ornamented the scabbard' (Dickinson, 1976: 258). This sword, like that from grave 11 at Petersfinger near Salisbury and Chessell Down on the Isle of Wight (Hawkes \& Page, 1967: 1116), was a composite consisting of parts made through the fifth and early sixth century. Similarly, the Staffordshire Hoard includes a series of parts of sword hilts, deposited at the same time but some of which were over 200 years old (Fischer \& Soulat, 2008; Mortimer \& Davis, 2018). Old swords, then, had particular value-so much so that, in some cases, recycled fittings were used to give the appearance of age. In addition, the identification of old or reused scabbards and their fittings suggest that every part of a sword could be retained or recycled (Brunning, 2013: 38). For example, some have their rings removed, presumably with a change in ownership or stewardship (see Evison, 1967: 63; Brunning, 2017). Swords were worn, modified, and used objects, and although the majority we have seem to have been deposited in contemporary mortuary contexts, these are probably only a small proportion of the swords in circulation (Härke, 2000).

\section{Swords and Bodies in Early Anglo- SAXON BURIALS}

We cannot know if early medieval swords had names like the swords in poetry (Brunning, 2013: 42; Mortimer \& Davis, 2018). However, in the use and wear of a weapon there is an amalgamation of body and sword, making a direct connection between the material object and the person, their identity and how they looked and were presented. This intermeshing of 
weapon and person is also seen in Early Anglo-Saxon mortuary contexts. To illustrate this, we have investigated Early Anglo-Saxon as well as Viking-age burials.

\section{Burials}

This project builds on the work of Härke (1992: 125-29) who plotted weapon locations onto a gridded representation of the grave in order to identify some patterning in the placement of shields and spears. To extend this and achieve a more nuanced impression of weapon locations we decided to apply GIS tools to locate each object relative to the grave and body. Initially, 407 weapons and 470 knives from seventeen Early Anglo-Saxon cemeteries were located within a spatially referenced Early Anglo-Saxon grave. For swords or knives, the point plotted was the intersection between the handle and the blade; for spears it was the junction of the socket and the blade; and for a shield boss the middle of the boss. This point marks the position these objects as found in their original burial, and it highlights not only their proximity of the weapons to the body but their relationship to it as well (Figure 1 and Table 1). A photograph of a grave without grave-goods was also spatially referenced within GIS. This image provides a good visual aid to understand the relative location of weapons to the person. The photograph used is of a supine individual since the majority ( 84 per cent) of weapon burials were supine inhumations (Mui, 2018: 119). This photograph can be used as a good approximation of the original body position. There is some slight variation, however, in the arm position. In the photograph, the individual's left shoulder is raised. The point data for spears traces a shoulder shape just below and to the right of the photographed shoulder. This was the location of most of shoulders. There is also some regional variation in body positioning with most variation evident in the north east of Britain, particularly at West Heslerton in North Yorkshire, a site included in this study (Mui, 2018: 105).

\section{Position of other weapons: knives, spears and shields}

Knives are found in both male and female graves (Härke, 1989) and, although they are found in a number of different positions (including the waist area, legs, chest, shoulders, and arms), the vast majority are found around the left hip: 314 of the 470 (67 per cent) knives are found around the left hip, with 81 knives (17 per cent) in the area of the right hip and 75 (16 per cent) elsewhere (Figure 2). Knives were an accessory of Early Anglo-Saxon dress, probably associated with a belt around the waist area (Owen-Crocker, 1986: 80). Spears, by contrast, seem to have been positioned in equal numbers on either the right- or left-hand side of the body: there are 120 (48.6 per cent) on the left, 125 (50.6 per cent) on the right, and 2 (0.9 per cent) in the middle. These figures do not seem to relate to right- or left-handedness and so should not be understood as reproducing how a spear was used or seen in association with the person. Most of these spearheads (227, or 92 per cent) where positioned around the shoulder or neck area and, significantly, the majority were outside the line of the body and arms, not placed across them. Shields were found in a variety of places: 19 (19 per cent) outside the body area, 25 (25.5 per cent) over the legs, and 47 (48 per cent) over the torso, meaning that 74.5 per cent were over the body, and, if the shield board was narrow (see the horseman shown holding a small shield on the Sutton Hoo helmet, and the Pliezhausen (Baden-Württemberg) 

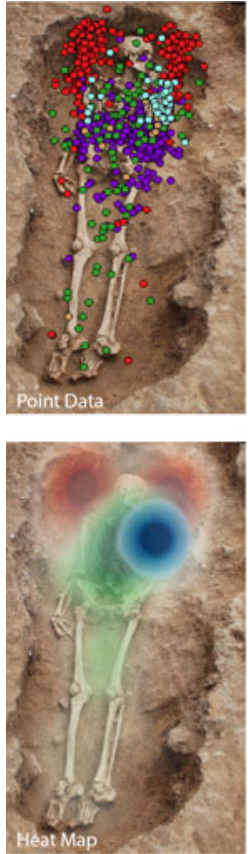
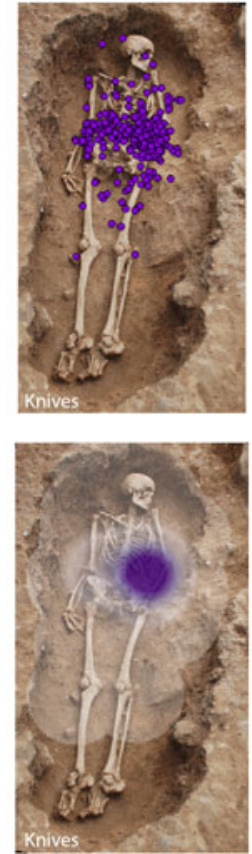
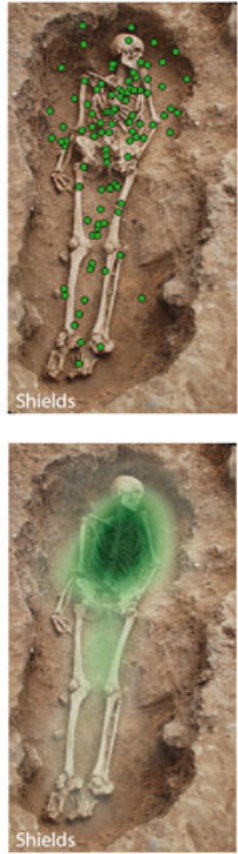
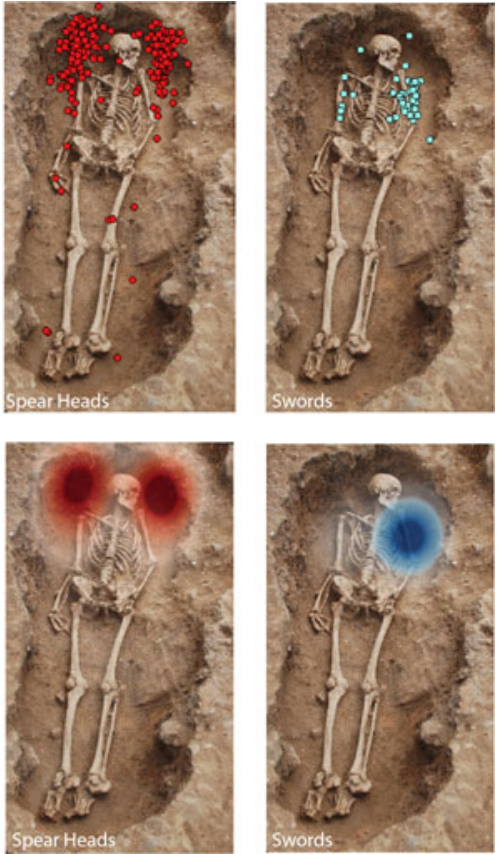

Figure 1. The location of weapons and knives found in 17 Early Anglo-Saxon cemeteries. The point data are along the top, and along the bottom, a heat map plotted at $0.5 \mathrm{~m}$, showing the area of highest density for each object, including: knives (purple), shields (green), spearheads (red), and swords (blue). Knives are concentrated on the left hip, shields along the body, spears to either side of the head, and swords were found with the hilt at shoulder and head height. Each point represents the intersection between the blade and the handle or for the shield its centre.

bracteates for illustrations of narrow shield boards), they need not have hidden the face. Shields provide protection for the body and, perhaps, were placed last amongst the objects, concluding access to the body and sheltering it from the soil which would fill the grave (Figure 1).

\section{Position of swords}

Swords, unlike knives, were not worn when buried; rather they were placed alongside the body, as demonstrated by Brunning's (2013: 150-51) study of 97 Kentish swords. In her sample, 47 per cent were directly beside the body; 25 per cent placed completely or partially on the body, 16 per cent touched or were touched by the body, and 7 per cent were cradled. In total, 95 per cent interacted directly with the deceased. In our investigation of 51 swords we found a similar association, with just three weapons placed away from the body. The majority, 44 (or 86 per cent) were placed on the left-hand side, with the handle and hilt towards the top of the grave. This position implies an intermeshing with the body as lived, not just the corpse, because it corresponds to proportions of left or right handedness. Seven swords were found on the right (14 per cent), which corresponds roughly with the expected proportion of left-handedness (around 10 or 20 per cent). Here the sword is placed on the side it was worn, rather than near the hand that used it. Interestingly, however, this laterality is not seen in the placement of spears or shields-weapons which do not appear to 
Table 1. Number of knives and weapons form Early Anglo-Saxon sites used in this study.

\begin{tabular}{llllll}
\hline Site & Knives & Shields & Spears & Swords & References \\
\hline Mucking & 109 & 11 & 56 & 8 & Hirst \& Clark, 2009 \\
Mucking 1 & 9 & 9 & 9 & 0 & Hirst \& Clark, 2009 \\
Dover & 58 & 10 & 25 & 13 & Evison, 1987 \\
Dover 2 & 48 & 4 & 21 & 7 & Parfitt \& Anderson, 2012 \\
Finglesham & 76 & 3 & 18 & 1 & Hawkes \& Grainger, 2006 \\
Deal & 40 & 6 & 18 & 3 & Parfitt \& Brugmann, 1997 \\
Blacknall Field & 24 & 11 & 14 & 4 & Annable \& Eagles, 2010 \\
Petersfinger & 10 & 6 & 6 & 2 & Leeds \& Short, 1953 \\
Collingbourne Ducis & 9 & 1 & 2 & 1 & Dinwiddy \& Stoodley, 2016 \\
Barrington & 36 & 10 & 17 & 0 & Malim \& Hines, 1998 \\
Alton & 14 & 5 & 16 & 4 & Evison, 1988 \\
Castledyke & 19 & 1 & 4 & 1 & Drinkall \& Foreman, 1998 \\
Westgarth Gardens & 4 & 6 & 5 & 2 & West, 1998 \\
West Heslerton & 4 & 7 & 17 & 1 & Haughton \& Powlesland, 1999 \\
Great Chesterford & 10 & 7 & 19 & 1 & Evison, 1994 \\
Sutton Hoo & & 1 & & 2 & Carver, 2005 \\
Taplow & & & & 1 & Stevens, 1884 \\
\hline
\end{tabular}

have the same connection to the person of the dead. Moreover, swords are found adjacent to the torso, either inside or just outside the arm position, and not at the waist, hip, or hand. Swords are not displayed in the grave as they were worn on the body, as knives are, but rather they are intertwined with the body. They are a separate object accompanying the person-in some cases individuals were even buried embracing their sword (Figure 2).

\section{Chamber burials}

It is instructive to compare these results from fifth- to seventh-century inhumations to those of seventh-century burial chambers. Since these are larger, it is possible for swords to be placed further from the body. However, most are still placed in direct association. In mound 17 at Sutton Hoo in Suffolk, where soil discoloration marks the location of the body even though it had largely disintegrated, the sword was placed with the person, just as in early inhumations. This was apparently accompanied by a buckle, knife, and purse at the hilt, suggesting it had a belt attached, but not worn (Carver, 2005: 129). The sword was on the person's right-hand side, with the hilt and grip parallel to the shoulder. In mound 1 at Sutton Hoo, the sword was at shoulder height, placed directly on top and to the right-hand side of a coffin (Carver, 2005: 182-95) (Figure 3). Similarly, according to the 1883 sketch of the Taplow burial, the sword is on the right-hand side placed high up, hilt and grip alongside the person's head, or on top of a coffin enclosing the body (Stevens, 1884). The chambered grave at Prittlewell in Essex is an interesting exception to this arrangement since here the sword was placed away from the body at 90 degrees to it, on the chamber floor, with the blade facing outwards and the hilt oriented towards the coffin (Hirst, 2004). Nevertheless, there is an association between sword and body. 

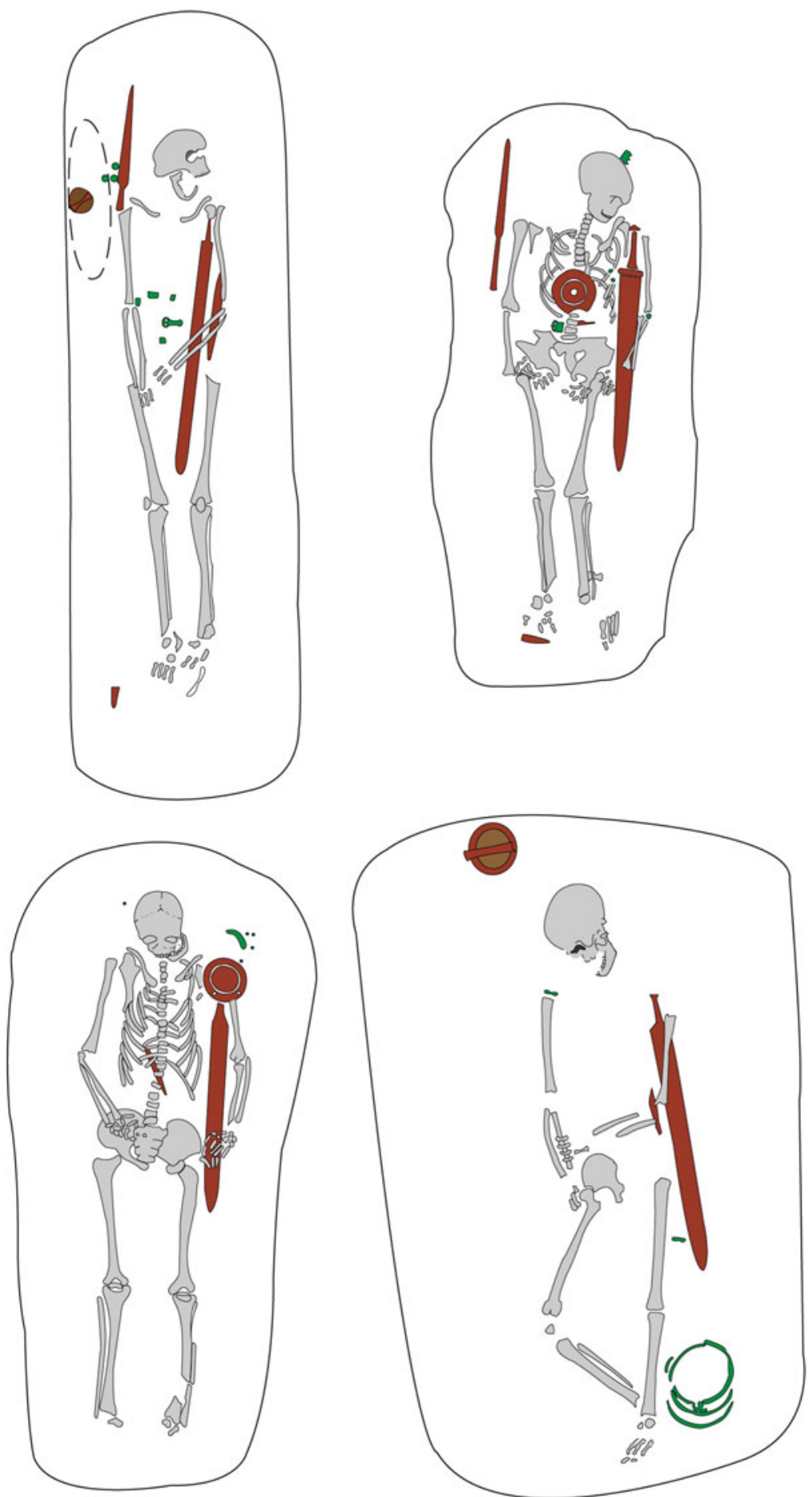

Figure 2. Four graves in which the person was placed embracing their sword. Top left: Dover Buckland grave 56; top right: Blacknall Field grave 22; bottom left: Blacknall Field grave 70; bottom right: Westgarth Gardens grave 66. 


\section{Swords and Bodies in Viking Age Burials}

The Early Anglo-Saxon placement of the sword with the body, and particularly its proximity to the shoulders, head, and face, is not universally replicated by later Viking-age burials in Britain, though the association of the sword with the body remains important. Soil conditions mean that there are not comparable numbers of Viking-age sword graves. However, from those that exist, there seems to have been much more variation in burial practice than is evident in Early Anglo-Saxon cases. Grave 511 at Repton, Derbyshire, has a sword on the left of the body with the hilt at the hip, suggesting that the weapon was placed as if worn on the body when buried (Biddle \& Kjølbye-Biddle, 1992; see Figure 4). Similarly, the grave at Ballateare on the Isle of Man has a sword low down in the coffin on the right-hand side of where the body would have been, presumably worn on the front of a belt or placed in the grave as if worn and turned outwards facing a funerary audience (Wilson, 2008: 31). Each of the three sword burials at Cumwhitton, Cumbria, seemed to have had different sword positions in relation to the body, though the disintegration of the bodies makes it impossible to be certain (Paterson et al., 2014; see Figure 4). Grave 25 has the sword to the centre left of the grave, adjacent to the body, worn or placed as worn in the grave. In grave 36 , the sword is also on the left of the grave, around the middle, but the blade crosses where the body would have been. In grave 24 , the sword is placed alongside the shoulder, so that the hilt would have been next to the face. Interestingly, in the Papa Westray burial on Orkney, the sword was placed on top of the body, turned around so that its tip concealed the person's temple and jaw, with the hilt over the lower thigh. Given the location of the shield boss, the sword is likely to have been placed alongside or on top of the shield, mimicking the position of the body below and representing the individual whose face was concealed under the shield. These burials probably date to between the eighth and tenth centuries (Hadley, 2006: 241-44).

\section{Viking-age boat burials}

In Viking Age boat burials, there is a tendency to place the sword next to the body. At Ardnamurchan in the Highlands of Scotland, the sword was placed parallel on the left-hand side of the body (based on teeth survival), with the hilt at head height (Harris et al., 2017). Similarly, at Westness on the island of Rousay in the Orkneys (Figure 5), a sword was found on the righthand side, although, in this case, a little away from the body. The body itself was placed to the left of the central axis of the boat, uniting the visual aesthetic of sword and body. This funerary tableau was constructed to position the body and sword as equal parts of an aesthetic whole across the centre of the boat (). The boat burial at Kaldárhöfði, Iceland, contained the poorlypreserved remains of two individuals, an adult and a child. The boat was quite small, with the weapons mostly found outside of it. However, based on the orientation deduced from teeth survival, the sword was placed with its hilt in closest proximity to the adult's head and shoulder (McGuire, 2009: 160-61). Finally, the multiple burial in a boat at Scar on the island of Sanday in Orkney also contained a sword associated with a specific individual. The person buried with this weapon was at the prow of the boat, on its left side, slightly flexed, and with a sword along the line of the person's spine. The sword seems to have been placed high along the individual's back, with the hilt at what was probably shoulder and head height. As this survey makes 

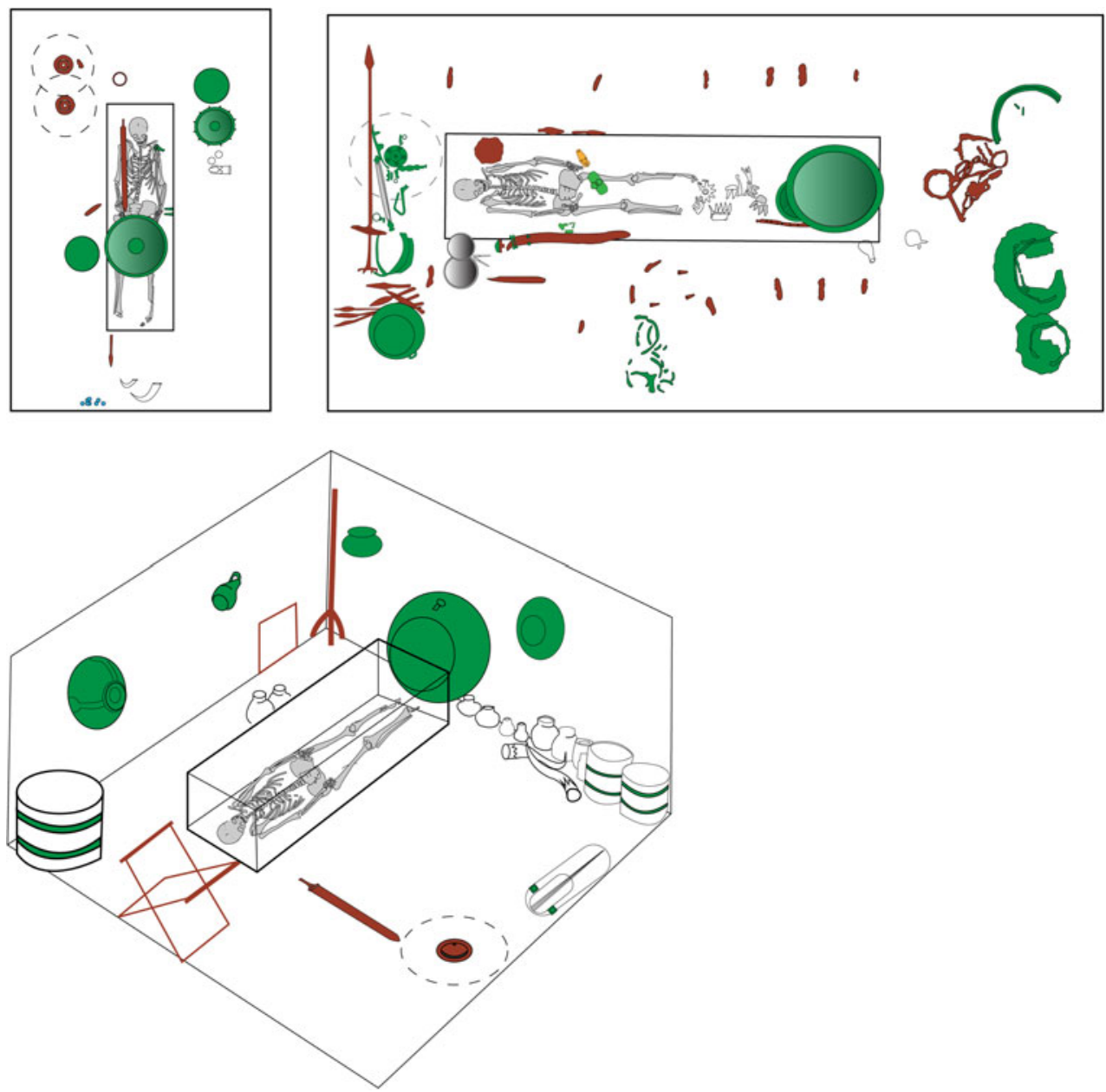

Figure 3. Anglo-Saxon princely burials. Top left: Taplow; top right: Sutton Hoo, mound 1; bottom: Prittlewell. After Stevens, 1884 (Taplow), Carver, 2005: 182 (Sutton Hoo) and Hirst, 2004 (Prittlewell). In each case human skeletons have been drawn within the coffin to illustrate the relationship between the sword and the body.

clear, there was a greater range of positions evident in Viking-age burial. From these few examples, it may be inferred that the sword was frequently worn, or placed as if worn, but also that it remained a component of the identity of the deceased.

\section{Chamber burials}

This significance in the placement of swords in Viking-age burials is also seen in the ninth- and tenth-century chamber burials at Birka in Sweden. For this study, we looked at the internal layout of 39 chamber graves, based on Arbman's (1943) notes and illustrations, with a particular focus on the location of swords, spears, shields, and knives. Unfortunately, as with the Viking-age burials in the UK and Iceland, human remains are typically poorly preserved. Each of these 39 chambers has a different size and shape, although they are all roughly rectangular. To facilitate comparison of these spaces, the central point of each chamber was 

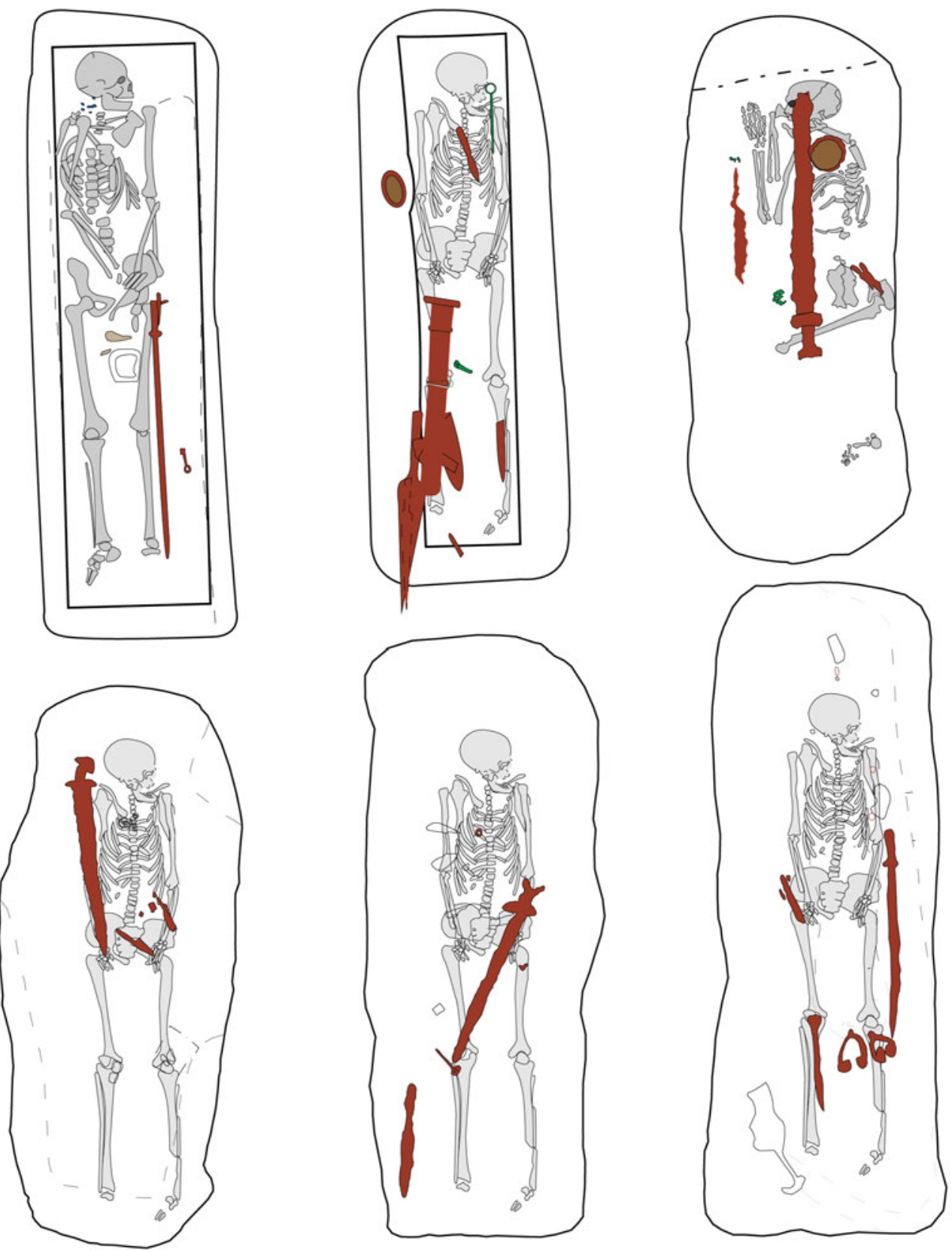

Figure 4. Six Viking-age graves with swords. Top row, left to right: Repton grave 511, Ballateare, and Papa Westray. Both Repton and Ballateare may have been in coffins. The bottom row shows from left to right: Cumwhitton graves 24, 36, and 25. The Ballateare and Cumwhitton graves have had human skeletons superimposed to highlight the different sword positions and how they may have interacted with the body. After Biddle E Kjolbye-Biddle, 1992 (Repton); Wilson, 2008: 31 (Ballateare); McLaren, 2016 (Papa Westray); Paterson, et al 2014 (Cumwhitton). 


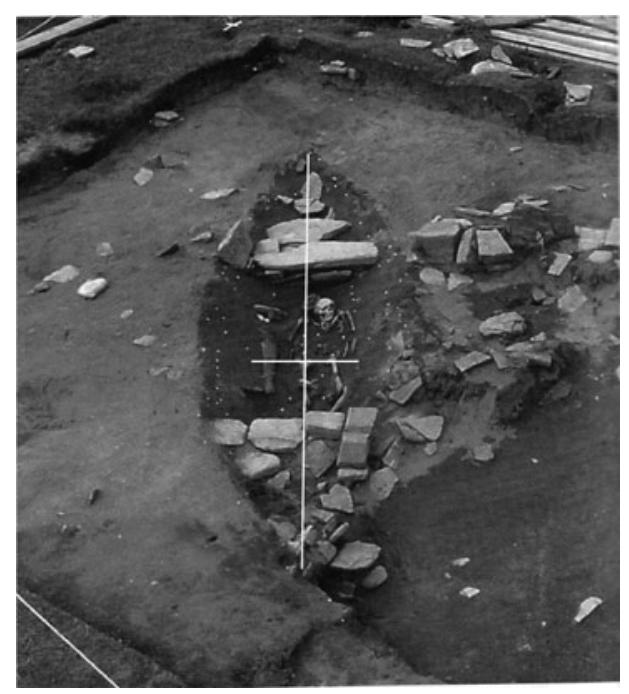

Figure 5. Viking-age boat burial at Westness, Rousay. The white cross provides a central point of reference: the buman remains and sword are placed on either side of the central point creating and aesthetic balance. This boat burial was excavated by Norsk Arkeologisk Selskap (Wilson $\mathrm{E}^{\circ}$ Hurst, 1969: 242).

measured and spatially referenced. The relative location of each object and the evidence for the head (skull or teeth), pelvis (pelvis or upper femur), or feet (feet or lower legs) of the deceased could be recorded in relation to this central point which then allowed comparison. The locations of these human remains were plotted onto the georeferenced chamber, and their clustering suggest that bodies were predominantly placed with the head to the north, the pelvis in the centre, and the legs to the south of the chamber. To aid visualisation, an illustration of a skeleton was placed within the chamber with its head, pelvis, and feet corresponding to a heat map of where the human remains were found.

The Birka graves investigated contained 138 weapons, including 26 swords, 30 spears, 42 shields and 40 knives (Table 2). The human remains tended to be located to the right of the chamber's centre
(Figure 6 and Figure 8 for the point data). Notably, the majority of swords were found to the left of centre, or on the body's right-hand side, placed next to the body whose position varied but was most probably supine, sitting, or in a semisupine sitting position, as in grave BJ 581 (Price, 2008; see Figure 7). Spears were placed across the chambers, on either the right or left side, with 17 spearheads above the centre and 13 below. These concentrate in three places, towards the bottom of the chamber and to the left, lower than the body, or on either the right- or lefthand side, and above the head (if supine), suggesting that laterality was not important. The lower spears tended to be placed on the right-hand side of the chamber and the body, perhaps thrown or placed in a forward facing or defensive position. Spears thus show a degree of complexity in their placement as either mobile actors within the mortuary space, or placed alongside the deceased. Knives were located all around the chambers but with a specific concentration corresponding to the pelvis, right of centre, implying that they were part of a worn costume, perhaps on a belt, like our Early Anglo-Saxon examples. At Birka the aesthetic of the burial chamber was important and, like the Westness boat grave, the body and the sword were placed around the central axis so that, when viewing the chamber, the sword and the person are aesthetically balanced. Both sword and body were surrounded by war-gear, i.e. spears, shields, horse equipment, horses, and arrows. As suggested above, the sword does not have the same association with the laterality of the body as that shown in the AngloSaxon examples but, rather, it is displayed prominently and centrally, harmonizing the aesthetic of the chamber. In this way, there is a distinction between weapons and a personal sword. Interestingly, swords were sometimes the target of grave 
Table 2. Quantity of knives, weapons, and human remains from Birka used in this study.

\begin{tabular}{|c|c|c|c|c|c|c|c|c|}
\hline Site & Knives & Shields & Spears & Swords & Sculls/Teeth & Location of pelvis & Feet & Reference \\
\hline Birka & 40 & 42 & 30 & 26 & 19 & 8 & 9 & Arbman, 19 \\
\hline
\end{tabular}

robbing, intended to subvert their role in the construction of a post-mortem personhood (Klevnäs, 2017), or within landscapes of fluctuating familial, and power dynamics (Raffield, 2014). The swords from the ship burials at Högom and Valsgärde were placed much more like the swords from the Early Anglo-Saxon examples: on the left, close to where adult bodies had been, as if worn or raised up the shoulder. This might imply that the Birka chamber graves were a very specific mortuary context designed to display the dead in a defined way.

\section{Discussion}

Both the literature and the archaeology suggest that swords had a specific
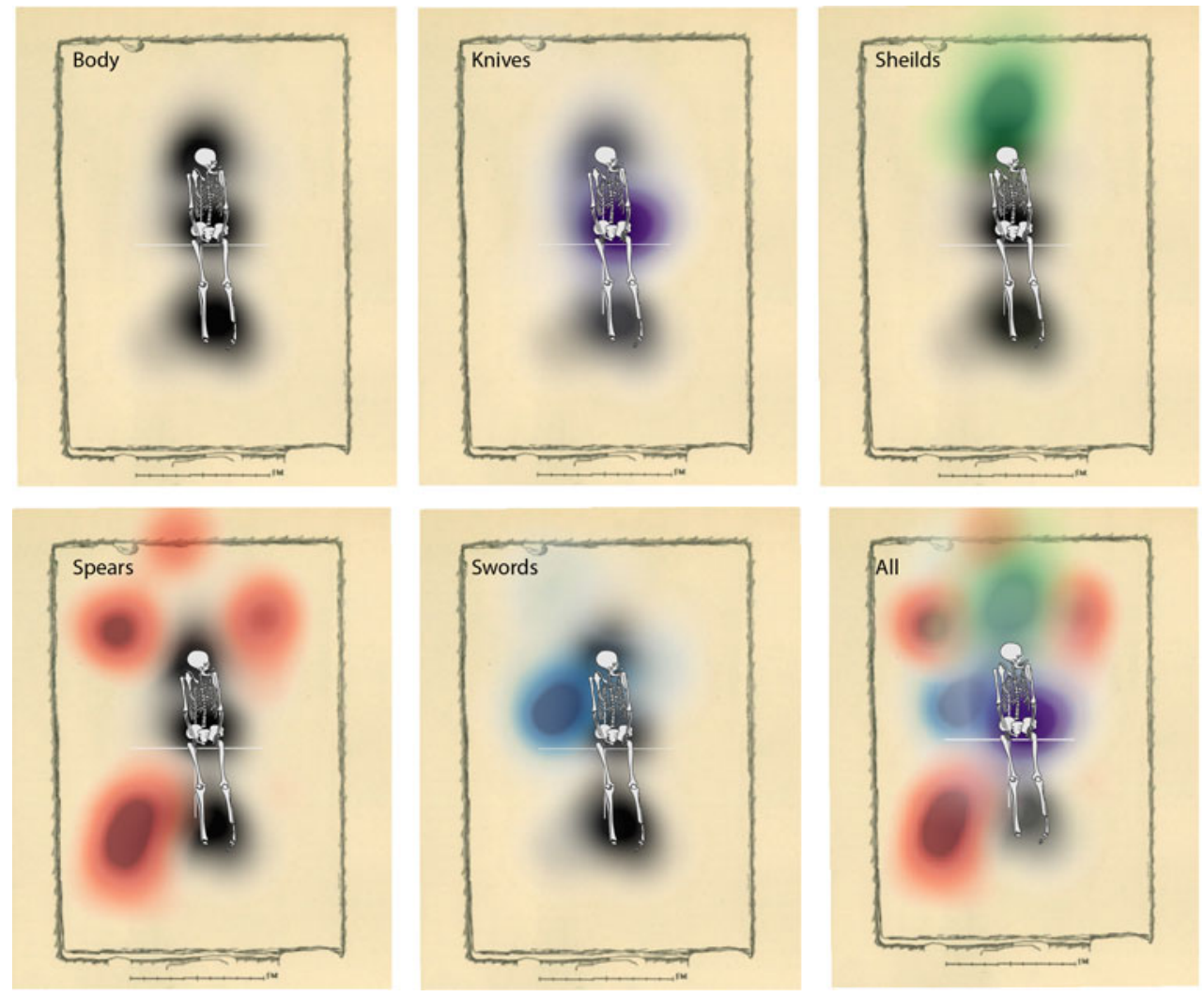

Figure 6. Heat maps illustrating the most common position in a Birka chamber of weapons in relation to the body. The positions of knives are marked in purple, shields in green, spearheads in red, and swords in blue. The body location is also shown in the heat maps in black, based on the most common location of skull or teeth, pelvis, and lower legs; human skeletons were superimposed on the most common positions to allow comparison with earlier illustrations. The white cross shows the central point of the chamber and each arm of the cross is $1 \mathrm{~m}$ in total. The image has been superimposed on a typical Birka chamber, with its contents removed. 


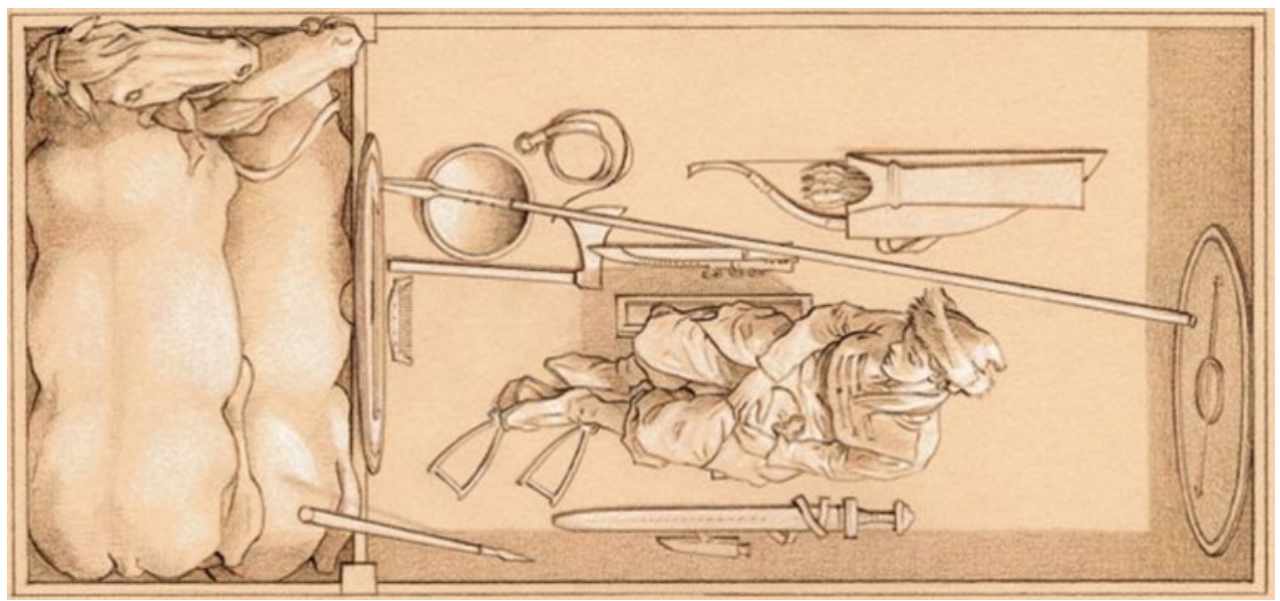

Figure 7. Grave BJ 581 at Birka, Sweden. An artistic reconstruction by Pórhallur Práinsson of the female burial with weapons laid out around her body.

Reproduced with permission from Neil Price.

status, and even a tendency to be anthropomorphized. It is not surprising that swords occupy a place in the poetic imagination (and perhaps broader cultural imagination), being closer to an ally than an instrument of war. The placement of the swords at the Birka, Sutton Hoo, Taplow, Högom and Valsgärde burial chambers, although different, suggests a specific, personal connection with the body. Spears, shields, and other types of war-gear (including horses, axes, seaxs, arrows, and even chain mail, which were not studied here because of their small numbers) seem to have been placed according to an expected aesthetic and without deliberate relationship to the body. The Viking flat graves in the UK incorporate the practical sword, placed as worn, or fixed to the body, inside the coffin: a hidden position that suggests the sword was understood to be a tool or weapon, rather than as the overt, symbolic display of power and identity seen in ship burials and chamber graves. Brunning's (2017) comprehensive study suggested that identifiable characteristics make a sword instantly recognisable, and old swords would convey or create histories for the observer. An association between the sword hilt and the head and shoulders of the person is notably evident from our study. When viewed as a part of a funerary performance, this placement seems to indicate that the sword is construed more as a companion than a tool, an eaxlgestealla or shoulder-companion just as in the Anglo-Saxon riddles, and to show the relationship between the deceased and their guðwine or 'friend in war' (Brady, 1979: 103-04). In life, the sword is worn on display at the waist, visible and intertwined with the individual; in literature, it is characteristically called 'on bearm', a phrase which may either mean lying across the lap or the bosom (e.g. Beo. 40b, 1143$4,2194 b)$ to indicate peace. In Maxims $I I$ the poet insists, 'sweord sceal on bearme', (25b), i.e. 'a sword should be in the lap'. In the grave, the sword was placed next to the corpse so that its distinctive characteristics could be displayed, placed prominently beside, and just below, the deceased's head and face, creating a proximity with the primary identity locator (Synnott, 1993: 22) and hence 

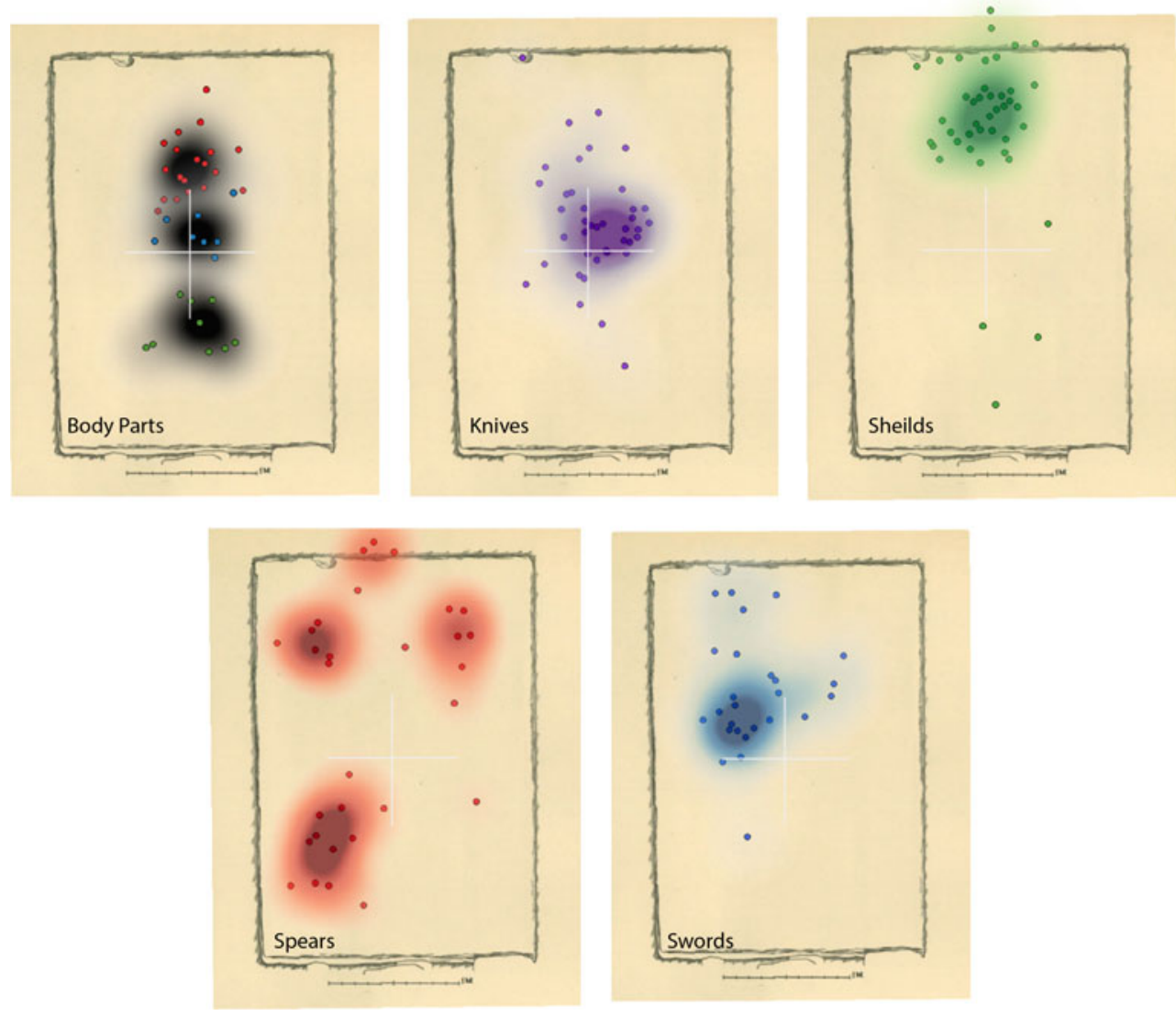

Figure 8. The Birka chamber layout. Top left (body parts): the red points show the position of teeth and skulls in relation to the chamber's central points; blue represents pelvises and green the lower legs. Top middle: the point data and heat map for knives, with the heat map plotted at $0.5 \mathrm{~m}$. The top right shows the same data for shields, the bottom right for spears, and the bottom left for swords.

intertwining the identities of the dead and the weapon.

Despite the similar emphasis on the aesthetic and material construction of the grave, especially the focus on the head and neck area, there are still significant differences between the Viking and Anglo-Saxon examples presented. Their social contexts are dissimilar in terms of religious change, personal mobility, and the fluctuation of royal or personal power shaping the respective social and material landscapes. Importantly, our study highlights this variation within the construction of mortuary space, with weapons enmeshed with Early Anglo-Saxon bodies, the sword being central to the layout of chamber and grave, in a way that other war-gear was not. Swords were part of the mortuary drama, and in the Viking burials they take on a prominent role in the interplay between material identity and personhood, displayed alongside the body.

In the literature, the distinctive weapon is usually, but not always, a sword and this, potentially, has implications for how we read graves in which the swords are not in association with the body. This may help explain the position of the Prittlewell sword away from the body, suggesting it was placed as a sign of 
wealth, of war, or as an indicator of social rank not enmeshed with the individual's identity as it was in other Early Anglo-Saxon examples. The woman in grave BJ 581 at Birka has a sword close to the body, but on her left-hand side, away from the centre of the grave (Hedenstierna-Jonson et al., 2017). She seems to have a stronger association with other weapons, including arrows, a sheath, and an axe, a placement that may suggest some more complex nuances in her identity (Figure 7). The location of this sword may have jarred with an observer who had witnessed weapon burials or the wearing of weapons. These types of burial narratives created tropes about their construction, and were familiar to the observers, from stories and poetry. Either BJ 581 was a burial conducted by someone unfamiliar with these tropes, or this unusual arrangement indicated something unconventional about the dead woman's identity. In this connection it is worth considering the example of Hervor. When claiming her father's sword, she stresses that she is his only child, presumably because a female heir was usual. On the other hand, although her father begs her not to claim the sword, he never suggests that her gender precludes her. The identity of the woman in BJ 581 might be similarly martial if unconventional. The latter seems likely since grave BJ 977 has a similar arrangement, in that the sword was positioned away from the central area of the grave and away from the body (inferred from the positions of buckles and knives). While these individuals could have been left-handed, especially BJ 977, laterality seems to have been less important in these chamber graves and so is less plausible as an explanation for the variation. It seems more likely that the variations in BJ 581 and BJ 977 indicate that martial identity in the Early Middle Ages was intricate and complex.

\section{Conclusion}

There is a clear and direct association between objects and bodies in early medieval graves. Some, like knives, were worn as clothing. Others, such as war-gear, may have signalled a social rank that was interdependent with martial status. Swords, however, seem to have been special objects, intermeshed with personhood and the performance of an elite but nuanced masculinity, just as they are in literature. This is evident in Early Anglo-Saxon graves and princely burials where the sword was embraced, placed by the head and shoulder, with the hilt accompanying the face, or positioned on top of a coffin, replicating the position of the body. In early Vikingage burials (such as the Repton grave), swords were probably seen in a more practical light, worn as objects and tools of battle. Equally, at Birka and in the North Sea boat graves, the sword and the body created an aesthetic whole, bringing a visual balance to the central area of the grave; swords were an important part of the aesthetic of commemoration, just as they were an important part of a hero's identity in the poetic corpus. A sword could be a means of transmitting identity, fulfilling obligations, or authenticating heirs. Swords are preserved in mortuary contexts but we cannot assume that all swords were buried. The literature emphasizes passing a weapon down, and there is geographic and chronological variation in sword deposition. Equally, a person might own, be given, or inherit multiple swords, which are in turn given, inherited, or placed in a grave. The inclusion of a sword in the grave was contingent on the mortuary context, inheritance, the person being buried, and the participants in the funeral. But we must also be wary. Swords placed in aesthetically awkward arrangements suggest a plurality of meaning and symbolism bound up with the sword, and its place 
within a grave. Moreover, burial without a sword does not mean that a person did not use one, own one, or merit one in life, a circumstance strongly supported by the many heroes who are depicted in literature as buried without their sword.

\section{Literary Sources}

All quotations from literary texts are from the following editions. All translations are our own unless otherwise stated.

Aertsen, H., \& Bremmer, R. , Jr. (eds.) 1994. Companion to Old English poetry. Amsterdam, VU University Press

Clark, G. 1968. The Battle of Maldon: A Heroic Poem. Speculum, 43.1: 52-71.

Dronke, U, (ed.) 1969-2011. The Poetic Edda. Oxford: Clarendon Press.

Fulk, R. D., Robert E. Bjork, John D. Niles (eds.) 2008. Klaber's Beowulf and The Fight at Finnsburg. Toronto: Toronto University Press.

Glorie, F (ed.) 1968. Aenigmata Tatwini. Corpus Christianorum, Series Latina 133. Turnhout: Brepols.

Jónsson, G. \& B. Vilhjálmsson, (eds.) 1943-44. Fornaldarsögur Nordurlanda. Reyjkjavík: Bókaútgáfan Forni.

Muir, B., (ed.) 2006. Exeter Anthology of Old English Poetry. Chicago, Chicago University Press.

Sigfússon, B. 1940. Reykdœla saga. Íslenzk Fornrit. Reykjavík: Hið íslenska bókmenntafélag.

Sveinsson, E. (ed.) 1954. Brennu-Njáls saga, Íslenzk fornrit. Reykjavík: Hið íslenzka fornritafélag.

\section{REFERENCES}

Annable, F.K. \& Eagles, B.N. 2010. The Anglo-Saxon Cemetery at Blacknall Field: Perwsey, Wiltshire (Wiltshire Archaeology and Natural History Society Monograph 4). Devizes: Wiltshire Archaeology and Natural History Society.

Arbman, H. 1943. Birka I: Die Gräber. Uppsala: Almqvist \& Wiksells.

Biddle, M. \& Kjølbye-Biddle, B. 1992. Repton and the Vikings. Antiquity, 66: 36-51.
Brady, C. 1979. Weapons in Beowulf: An Analysis of the Nominal Compounds and an Evaluation of the Poet's Use of Them. Anglo-Saxon England, 8: 79-142.

Brunning, S. 2013. The Living Sword in Early Medieval Northern Europe: An Interdisciplinary Study. Unpublished $\mathrm{PhD}$ dissertation, University College London.

Brunning, S. 2017. Crossing Edges? 'PersonLike' Swords in Anglo-Saxon England. In: S. Semple, C. Orsini \& S. Mui, eds. Life on the Edge: Social, Religious and Political Frontiers in Early Medieval Europe (Neue Studien zur Sachsenforschung 6). Braunschweig: Braunschweigisches Landesmuseum with Internationales Sachsensymposion, pp. 409-18.

Carver, M.O.H. 2005. Sutton Hoo: A SeventhCentury Princely Burial Ground and its Context. London: The British Museum.

Culbert, T. 1960. The Narrative Functions of Beowulf's Swords. The Journal of English and Germanic Philology, 59: 13-20.

Danet, B \& Bogoch, B. 1994. Orality, Literacy and Performativity in AngloSaxon Wills. In: J. Gibbons, ed. Language and the Law. London \& New York: Longman, pp. 100-135.

Dickinson, T. 1976. The Anglo-Saxon Burials Sites of the Upper Thames Region, and their Bearing on the History of Wessex, circa ad 400-700. Unpublished D.Phil. dissertation, University of Oxford.

Dinwiddy, K.E. \& Stoodley, N. 2016. An Anglo-Saxon Cemetery at Collingbourne Ducis, Wiltshire. Salisbury: Wessex Archaeology.

Drinkall, G. \& Foreman, M. 1998. The AngloSaxon Cemetery at Castledyke South, Barton-on-Humber (Sheffield Excavation Reports 6). Sheffield: Sheffield Academic Press.

Evison, V.I. 1967. The Dover Ring-Sword and Other Ring-Swords and Beads. Archaeologia, 101: 63-118.

Evison, V.I. 1987. Dover: The Buckland AngloSaxon Cemetery. London: Historic Buildings and Monuments Commission for England.

Evison, V.I. 1988. An Anglo-Saxon Cemetery at Alton, Hampshire. Winchester: Hampshire Field Club and Archaeological Society.

Evison, V.I. 1994. An Anglo-Saxon cemetery at Great Chesterfield, Essex (CBA Research Report 91). York, Council for British Archaeology. 
Felder, K. 2015. Networks of Meaning and the Social Dynamics of Identity. An Example from Early Anglo-Saxon England. Papers from the Institute of Archaeology, 25: 1-20.

Fischer, S. \& Soulat J. 2008. The Typochronology of Sword Pommels from the Staffordshire Hoard [online] [accessed 29 March 2018]. Available at: <http:// finds.org.uk/staffshoardsymposium/papers/ svantefischerandjeansoulat>

Fowler, C. 2010a. Pattern and Diversity in the Early Neolithic Mortuary Practices of Britain and Ireland: Contextualising the Treatment of the Dead. Documenta Praebistorica, 37: 1-22.

Fowler, C. 2010b. Relational Personhood as a Subject in Anthropology and Archaeology: Comparative and Complementary Analysis. In: D. Garrow \& T. Yarrow, eds. Archaeology and Anthropology: Understanding Similarities, Exploring Difference. Oxford: Oxbow, pp. 137-59.

Hadley, D. 2006. The Vikings in England: Settlement, Society and Culture. Manchester: Manchester University Press.

Hadley, D. 2008. Warriors, Heroes and Companions: Negotiating Masculinity in Viking-Age England. In: S. Crawford \& H. Hamerow, eds. Anglo-Saxon Studies in Archaeology and History, 15: 270-84.

Härke, H. 1989. Knives in Early Saxon Burials: Blade Length and Age at Death. Medieval Archaeology, 33: 144-48.

Härke, H. 1992. Angelsächsische Waffengräber des 5. bis 7. Jahrhunderts (Zeitschrift fuer Archäologie des Mittelalters Beiheft 6). Köln: Rheinland Verlag \& Bonn: Rudolf Habelt.

Härke, H. 2000. The Circulation of Weapons in Anglo-Saxon Society. In: F. Theuws \& J.L. Nelson, eds. Rituals of Power from Late Antiquity to the Early Middle Ages (The Transformation of the Roman World 8). Leiden, Boston \& Cologne: Brill, pp. 377-99.

Harris, O.J.T., Cobb, H., Batey, C.E., Beaumont, J., Montgomery, J., Gray, H. et al. 2017. Assembling Places and Persons: A Tenth-century Viking Boat Burial from Swordle Bay on the Ardnamurchan Peninsula, Western Scotland. Antiquity, 91: 191-206.

Harrison, S.H. 2015. 'Warrior graves'? The Weapon Burial Rite in Viking Age Britain and Ireland. In: J.H. Barrett \& S.J. Gibbon, eds. Maritime Societies of the Viking and Medieval World (Society for Medieval Archaeology Monograph 37). Leeds: Maney, pp. 299-319.

Haughton, C. \& Powlesland, D. 1999. West Heslerton: The Anglian Cemetery, Volume 2: Catalogue of the Anglian Graves and Associated Assemblages. Yedingham: Landscape Research Centre \& English Heritage.

Hawkes, S.C. \& Grainger, G. 2006. The Anglo-Saxon Cemetery at Finglesham, Kent (Oxford University School of Archaeology Monograph 64). Oxford: Oxford University School of Archaeology.

Hawkes, S.C. \& Page, R.I. 1967. Swords and Runes in South-East England. Antiquaries Journal, 47: 1-26.

Hedenstierna-Jonson, C, Kjellström, A, Zachrisson, T, Krzewińska, M., Sobrado, V., Price, N. et al. 2017. A Female Viking Warrior Confirmed by Genomics. American Journal of Physical Anthropology, 164: 853-860. https://doi. org/10.1002/ajpa.23308

Hirst, S.M. 2004. The Prittlewell Prince. London: Museum of London Archaeology Service.

Hirst, S.M., \& Clark, D. 2009. Excavations at Mucking. Volume 3: The Anglo-Saxon Cemeteries Parts 1 and 2. London: Museum of London Archaeology.

Hockey, J., Dilley, R., Robinson, V. \& Sherlock, A. 2013. Worn Shoes: Identity, Memory and Footwear. Sociology Research Online, 18(1) 20. http://www.socresonline. org.uk/18/1/20.html

Hockey, J., Dilley, R., Robinson, V. \& Sherlock, A. 2015. 'There's Not Just Trainers or Non-Trainers, There's Like Degrees of Trainers': Commoditisation, Singularisation and Identity. Journal of Material Culture, 20: 21-42. https://doi. org/10.1177/1359183514560665

Ingold, T. 2010. Bringing Things to Life: Creative Entanglements in a World of Materials (ESRC National Centre for Research Methods, Realities Working Paper 15). Manchester: University of Manchester [online] [accessed 14 February 2019]. Available at: <http://eprints.ncrm. ac.uk/1306/1/0510_creative_entanglements. pdf>

Jurasinski, S. 2006. Ancestral Privileges: Beowulf, Law, and the Making of Germanic 
Antiquity. Morgantown (WV): West Virginia University Press.

Khanmohamadi, S.A. 2017. Durendal, Translated: Islamic Object Genealogies in the chansons de geste. Postmedieval. 8: 321-33. https://doi.org/10.1057/s41280017-0061-3

Klevnäs, A.M. 2017. Imbued with the Essence of the Owner: Personhood and Possessions in the Reopening and Reworking of Viking-Age Burials. European Journal of Archaeology, 19: 456-76.

Kopytoff, I. 1986. The Cultural Biography of Things: Commoditization as Process. In A. Appadurai, ed. The Social Life of Things. Cambridge: Cambridge University Press, pp. 64-91.

Leeds, E.T. \& Shortt, H. de S. 1953. An Anglo-Saxon Cemetery at Petersfinger, Near Salisbury, Wiltshire. Salisbury: South Wiltshire and Blackmore Museum.

Lund, J. 2017. Connectedness with Things. Animated Objects of Viking Age Scandinavia and Early Medieval Europe. Archaeological Dialogues, 24: 89-108.

Malim, T \& Hines, J. 1998. The Anglo-Saxon Cemetery at Edix Hill (Barrington A), Cambridgeshire (CBA Research report 112). York: Council for British Archaeology.

Martin, T.F. 2014. (Ad)Dressing the AngloSaxon Body: Corporeal Meanings and Artefacts in Early England. In: P. Blinkhorn \& C. Cumberbatch, eds. The Chiming of Crack'd Bells: Recent Approaches to the Study of Artefacts in Archaeology (British Archaeological Reports International Series 2677). Oxford: Archaeopress, pp. 27-38.

McGuire, E. 2009. Manifestations of Identity in Burial: Evidence from Viking Age Graves in the North Atlantic Diaspora. Unpublished $\mathrm{PhD}$ dissertation, University of Glasgow.

McLaren, D. 2016. Recent Burials from Papa Westray, Orkney: An Overview and Initial Thoughts. Blog concerning a presentation to the Centre for Scottish and Celtic Studies, University of Glasgow [online] [accessed 30 May 2018]. Available at: <http://cscs.academicblogs.co.uk/an-earlymedieval-miscellany/>

Miller. 2007. Is a Gift Forever? Representations, 100.1, Fall: 13-22.

Mortimer, P. \& Davies, S. 2018. Staffordshire Hoard. In: P. Mortimer \& M. Munker, eds. The Sword in Anglo-Saxon England:
From the 5th to the 7th Century. Ely: Anglo-Saxon Books, pp. 69-72.

Mui, S. 2018. Dead Body Language: Deciphering Corpse Positions in Early Anglo-Saxon England. Unpublished PhD dissertation, University of Durham.

Neidorf, L. 2016. Philology, Allegory, and the Dating of Beowulf. Studia Neophilologica, 88: 97-115.

Orkisz, J. 2016. Pole-weapons in the Sagas of Icelanders: A Comparison of Literary and Archaeological Sources. Acta Periodica Duellatorum, 4.1: 177-212.

Owen-Crocker, G.R. 1986. Dress in AngloSaxon England. Manchester, Manchester University Press.

Parfitt, K. \& Anderson, T. 2012. Buckland Anglo-Saxon Cemetery, Dover. Excavations 1994. Canterbury: Canterbury Archaeological Trust.

Parfitt, K. \& Brugmann, B. 1997. The AngloSaxon Cemetery on Mill Hill, Deal, Kent (Society for Medieval Archaeology Monograph Series 14). London: The Society for Medieval Archaeology.

Paterson, C., Parsons, A.J., Newman, R.M., Johnson, N. \& Howard Davis, C. 2014. Shadows in the Sand: Excavation of a Viking Age Cemetery at Cumwhitton, Cumbria. Oxford: Oxbow.

Paz, J. 2015. Nonbuman Voices in Anglo-Saxon Literature and Material Culture. Manchester, Manchester University Press.

Price, N. 2008. Dying and the Dead: Viking Age Mortuary Behaviour. In: N. Price \& S. Brink, eds. The Viking World. London: Routledge, pp. 257-73.

Price, N. 2010. Passing into Poetry: VikingAge Mortuary Drama and the Origins of Norse Mythology. Medieval Archaeology, 54: $123-56$.

Raffield, B. 2014. 'A River of Knives and Swords': Ritually Deposited Weapons in English Watercourses and Wetlands during the Viking Age. European Journal of Archaeology, 17: 634-55.

Sebo, E. 2011. Beowulf Hondbana: The Literary Context for Emending Line 1520b. Neophilologus, 95: 639-48. https:// doi.org/10.1007/s11061-011-9269-x

Sebo, E. 2015. Ne Sorga: Grief and revenge in Beowulf. In J. Wilcox, A. Jorgensen \& F. McCormack, eds. Anglo-Saxon Emotions. London: Ashgate, pp. 177-92.

Steele, V. 1998. Shoes. A Lexicon of Style. London: Scriptum. 
Stevens, J. 1884. On the remains found in an Anglo-Saxon tumulus at Taplow, Buckinghamshire. Journal of the British Archaeological Society, 40: 61-71.

Synnott, A. 1993. The Body Social: Symbolism, Self and Society. London: Routledge.

Tollerton, L. 2011. Wills and Will-making in Anglo-Saxon England. Woodbridge: York Medieval Press.

van Houts, E. 1999. Memory and Gender in Medieval Europe, 900-1200. Basingstoke: Palgrave Macmillan.

Webster, L. 1998. Archaeology and Beowulf. In: B. Mitchell \& F. C. Robinson, eds. Beowulf: An Edition: Oxford: Wiley, pp. 183-94.

West, S.E. 1988. The Anglo-Saxon Cemetery at Westgarth Gardens, Bury St Edmunds, Suffolk: Catalogue (East Anglian Archaeology Report 38). Bury St Edmunds: Suffolk County Planning Department.

Williams, H. 2005. Keeping the Dead at Arm's Length: Memory, Weaponry and Early Medieval Mortuary Technologies. Journal of Social Archaeology, 5: 253-75.

Wilson, D.M. \& Hurst, D.G. 1969. Medieval Britain in 1968. Medieval Archaeology 13: 230-87.

Wilson, D.M. 2008. The Vikings in the Isle of Man. Aarhus: Aarhus University Press.

\section{Biographical Notes}

Duncan Sayer is Reader in Archaeology at the University of Central Lancashire, UK. $\mathrm{He}$ excavated the early medieval cemetery at Oakington, Cambridgeshire. Duncan previously authored a book titled Ethics and Burials Archaeology and edited Mortuary Practice and Social Identity in the Middle Ages. $\mathrm{He}$ is co-editor for a book series focused on Social Archaeology and Material Worlds with Manchester University Press. https://orcid.org/00000002-2769-1281

Address: School of Forensic and Applied Sciences, Maudland Building, University of Central Lancashire, Preston, UK dsayer@uclan.ac.uk

Erin Sebo is Lecturer in Medieval Literature and Languages at Flinders University, South Australia. She has held positions at Monash University, Trinity College Dublin, and Queens University Belfast and is a member of the Australia Research Council Centre for Excellence for the Study of the History of Emotions and has published widely on Anglo-Saxon epic poetry, conflict, and emotion. https:// orcid.org/0000-0001-8845-1882

Address: College of Humanities, Arts and Social Sciences, Sturt Road, Bedford Park | South Australia | 5042 Flinders University, Adelaide, Australia erin.sebo@ flinders.edu.au

Kyle Hughes is Visiting Research Associate at Trinity College Dublin, Ireland. He was awarded his $\mathrm{PhD}$ there in 2017 for research done on communities, peacemaking, and law in the sagas of the Icelanders. He has given many public lectures on Viking burials, including a series on the Larne Viking burial for the Larne Museum and Arts Centre in the Autumn of 2017. His article, 'What is "Good Law"? Law as Communal Performance in the Íslendingasögur,' will be published by de Gruyter as part of the collection 'Ergänzungsbände zum Reallexikon der Germanischen Altertumskunde' in 2018, and he is currently in the process of revising and expanding his thesis for publication.

Address: School of English, Trinity College Dublin, Dublin, Ireland 


\section{Des armes à double tranchant : les épées, les corps et l'individualité en archéologie et en littérature du début du Moyen Age}

Les épées font partie de l'identité d'un héros dans la littérature anglo-saxonne et viking. Outre leur fonction d'arme, elles sont un agent matériel représentant les actions d'un individu, l'expression physique de son identité. Dans cet article nous rassemblons les données archéologiques ainsi que celles contenues dans les sources littéraires concernant les épées d'époque anglo-saxonne et viking et soutenons que ces éléments convergents nous permettent de discerner la construction d'identités funéraires et l'expression de personnalités spécifiques. La position des épées dans un contexte funéraire est importante car elles sont placées près du corps et s'entremêlent à la personne physique. Les épées n'étaient pas que des objets, elles faisaient partie des gens, en étaient inséparables et enchevêtrées avec eux. Lors des funérailles, on les exposait dans une esthétique faisant appel aux émotions. Les épées, serrées sur le corps ou placées à côté des épaules et de la tête, exprimaient leur propre identité. Les sources littéraires relatent des évènements extraordinaires tout en décrivant des coutumes familières et en reflétant une partie de l'esthétique funéraire. Mais certaines sépultures, comme celles de Prittlewell ou de Birka (tombe 581), ne se conforment pas aux règles, ce qui aurait gêné un observateur connaissant les coutumes de l'époque. Ces exceptions auraient certainement rehaussé le caractère peu conventionnel ou nuancé de certains individus. Translation by Madeleine Hummler

Mots-clés: épées, esthétique funéraire, individualité, littérature, corps, époque anglo-saxonne, époque viking, Birka, réalisation de la masculinité

\section{Eine zweischneidige Waffe: Schwerter, Körper und persönliche Identität in der Archäologie und Literatur des Frühmittelalters}

In der angelsächsischen und wikingerzeitlichen Literatur gehören die Schwerter zur Identität eines Helden. Außer seiner Funktion als Waffe vertritt das Schwert materiell die Leistungen einer Person und ist der physische Ausdruck der Persönlichkeit dieses Menschen. In diesem Artikel werden die Beweise aus der Literatur und die archäologischen Angaben über die angelsächsischen und wikingerzeitlichen Schwerter zusammengebracht; diese verschiedenen Stränge scheinen zusammenzulaufen und zeigen, dass Identitäten im Tod geschaffen wurden und spezifische Individualitäten zum Ausdruck kamen. Die Lage der Schwerter in den Gräbern ist bedeutend, weil die Waffen nahe am Körper getragen wurden und sich mit der physischen Person vermischten. Ein Schwert war nicht nur ein Gegenstand, es gehörte zur Person; die beiden waren untrennbar und miteinander vernascht und waren an einer gefühlsgeladenen Trauerästhetik beteiligt. Das Schwert wurde umarmt oder lag nahe am Kopf und Schultern eines Bestatteten und es vermittelte seine eigene Identität. Die schriftlichen Quellen berichten über außergewöhnliche Ereignisse aber beschreiben geläufige Bräuche und widerspiegeln teilweise eine Trauerästhetik. Es gibt aber Ausnahmen: Die Gräber von Prittlewell und Birka (Grab 581) enthielten Schwerter, die nicht in der üblichen Lage waren; dies hätte einen zeitgenössischen Beobachter gestört. Diese Ausnahmen haben wohl außergewöhnliche oder nuancierte Individualitäten hervorgehoben. Translation by Madeleine Hummler

Stichworte: Schwerter, Trauerästhetik, Individualität, Literatur, Körper, Wikinger, Angelsachsen, Birka, Vorstellung der Männlichkeit 